\title{
Ethnobotanical study of antimalarial plants in the middle region of the Negro River, Amazonas, Brazil
}

\author{
Bernardo TOMCHINSKY ${ }^{*}$, Lin Chau MING ${ }^{1}$, Valdely Ferreira KINUPP², Ari de Freitas HIDALGO², \\ Francisco Célio Maia CHAVES ${ }^{4}$ \\ 1 Universidade Estadual Paulista, Faculdade de Ciências Agronômicas, Departamento de Horticultura, Laboratório de Plantas Medicinais e Etnobotânica, Rua José Barbosa de \\ Barros, 1780, Botucatu, São Paulo, Brazil, CEP 18.610-307 \\ 2 Instituto Federal de Educação do Amazonas, Herbário EAFM/IFAM, Av. Cosme Ferreira, 8045, Manaus, Amazonas, Brazil, CEP 69083-000 \\ 3 Universidade Federal do Amazonas, Faculdade de Ciências Agrárias, Av. General Rodrigo Otávio, S/N, Manaus, Amazonas, Brazil, CEP 69077-000 \\ ${ }^{4}$ Empresa Brasileira de Pesquisa Agropecuária, Rodovia AM-10, km 29, Manaus, Amazonas, Brazil, CEP 69010-970 \\ * Corresponding author: btomchinsky@hotmail.com
}

\section{ABSTRACT}

The middle Rio Negro region is an interesting place to seek novel antimalarial compounds because of the traditional knowledge of the Amazon population in conjunction with the high biodiversity of the region. The objective of this work was to study the use of antimalarial plants in Barcelos, state of Amazonas, Brazil. Fifty-two local specialists from eight different communities were interviewed over one year. The identified plants were collected with the assistance of local specialists, classified to species level and deposited in herbarium. In total, 55 antimalarial plants were identified in use in the region, of which 16 had not been previously reported in other published studies. Many factors could be involved with the use of antimalarial plants by the Barcelos population, such as the accessibility of these medicinal plants, efficiency and safety of using these plants, the accessibility to drugs or other medical treatments, plant bitterness, and the gender of the interviewees. Our results indicate that the population of Barcelos possesses an extensive knowledge on the use of a diverse array of antimalarial plants, and may contribute to the development of novel antimalarial compounds.

KEYWORDS: malaria, ethnobotany, Amazonia, medicinal plants, traditional knowledge

\section{Etnobotânica de plantas antimaláricas no médio Rio Negro, Amazonas, Brasil}

\section{RESUMO}

O conhecimento tradicional da população amazônica, associado à grande biodiversidade da região, faz do médio Rio Negro um lugar propício para a pesquisa de novos remédios antimaláricos. O objetivo deste trabalho foi estudar o uso de plantas antimaláricas no município de Barcelos, Amazonas, Brasil. Ao longo de um ano foram entrevistados 52 especialistas de oito comunidades de Barcelos. As plantas indicadas foram coletadas com o auxilio dos especialistas, identificadas e depositadas em herbário. Foram mencionadas 55 plantas antimaláricas, das quais 16 nunca foram citadas em outros trabalhos previamente publicados. Muitos fatores podem estar associados ao uso destas plantas antimaláricas, tais quais o acesso a estas plantas, sua eficiência e segurança, o acesso a outros tratamentos médicos, o amargor das plantas e o gênero das pessoas entrevistadas. Nossos resultados indicam que a população de Barcelos é detentora de um rico conhecimento sobre o uso de plantas medicinais antimaláricas e pode contribuir para o desenvolvimento de novas drogas antimaláricas.

PALAVRAS-CHAVE: malária, etnobotânica, Amazônia, plantas medicinais, conhecimento tradicional 


\section{INTRODUCTION}

Malaria remains as one of the major tropical diseases worldwide (Bremen 2011). In 2015, 214 million cases and 438,000 deaths were reported, most of them children less than five years old (WHO 2015). Malaria is considered as one of the neglected diseases, which are usually present in poor populations in tropical areas, and which receive little attention from governments and the pharmaceutical industry (Krettli 2008). Malaria is caused by an infection with protozoans of the genus Plasmodium, and is transmitted by female mosquitos Anopheles spp. Clinical symptoms of malaria include cycles of fevers, chills, and headaches, and infection can affect the liver, kidneys, and nervous system, causing brain damage, which can lead to serious complications in infected individuals and result in death (WHO 2010; WHO 2015).

Malaria has a large economic and social impact in its endemic areas in Brazil. In 2013, 143,000 cases and 30 deaths were reported in the country. The Amazon region concentrated $99 \%$ of malaria cases in Brazil. Plasmodium vivax is the most frequent infection agent in Brazil, identified in $84 \%$ of all cases, followed by $P$. falciparum, identified in $16 \%$ of cases (SVS 2015; WHO 2015). Although Brazil has a universal public health system, eradication of the disease across the country is difficult due to factors such as the incorrect administration of drugs, the presence of isolated populations in the forest, the movement of people, particularly in border areas, and the expanding colonization fronts in the Amazon region (Melo 1985; Coimbra 1998; Singer and Caldas 2001).

Incorrect use of drugs and the evolution of Plasmodium spp. contribute to the development of increasing resistance to currently available antimalarial drugs, which creates an urgent need to identify novel therapeutic antimalarial compounds (Alecrim et. al. 1999, Krettli 2008, WHO 2010; WHO 2015). Ethnobotanical research of medicinal plants remains as one of the most important means for the identification of new, efficient, and safe compounds for the control of malaria (Ginsburg and Deharo 2011; Graz et al. 2011; Willcox et al 2010).

The populations that live along the Negro River, in the western Brazilian Amazon, use a wide variety of plants for the treatment of numerous diseases (Silva et al. 2007). The Negro River region is suitable for the survey of novel drugs, because the region has a conserved forest, several endemic plant species, and the largest indigenous population of Brazil, comprising 24 ethnic groups (Sufredine and Daly 2001).

Therefore the objective of this study was to profile the use of antimalarial plants by traditional communities in the municipality of Barcelos, in the middle Negro River, Amazonas, Brazil.

\section{MATERIALS AND METHODS}

For this study, approval was obtained from all the involved communities, from the Ethics Research Committee (CEP) of São Paulo State University (UNESP/FMB no 3425-2010) and from the Brazilian National Genetic Heritage Council (CGEN n¹11 / 2012).

The fieldwork was carried out between July 2012 and July 2013 in eight communities in the municipality of Barcelos, state of Amazonas, Brazil (Figure 1), on the margins of the Negro River, the largest blackwater river of the Amazon basin, that originates in the Colombian Andes and crosses Amazonas from its northwestern border to the capital city of Amazonas, Manaus, where it joins with the Amazonas River. Barcelos is located in the middle region of the Negro River, $496 \mathrm{~km}$ upriver from Manaus.

The municipality of Barcelos covers an area of 123,000 $\mathrm{km}^{2}$ and has a population of 27,000 inhabitants, the majority of them (56\%) being indigenous (IBGE 2016). The Human Development Index (HDI) of Barcelos is considered low $(0,500)$ (IBGE 2016). The incidence of malaria in the city is high, with more than 100 cases per thousand inhabitants registered each year (Suarez-Muttis and Coura 2007; SVS 2015). The surveyed communities were indicated by the Barcelos Municipal Health Office according to their incidence of malaria (Table 1). Fifty two persons from the eight target communities were identified by locals according to their knowledge of medicinal plants using the snowball method (Alexiades, 1996). Semi-structured interviews were conducted in order to understand socio-cultural aspects, the comprehension of malaria, and the use of medicinal plants for treatment of the disease (Supplemental Material, Annex S1).

The identified plants were collected with assistance of the local specialists, identified to the lowest possible taxonomic level and deposited in the herbarium of the Instituto Federal de Educação, Ciência e Tecnoclogia do Amazonas (EAFM/ IFAM) (Manaus, Amazonas). The curator of the herbarium Valdely F. Kinupp identified all plant species. The geographical origin of the species (native or exotic to Amazonia), was determined in accordance with Flora do Brasil $2020 \mathrm{em}$ construção (2017). We reviewed available information about the phytochemical composition of and biological essays carried out for each of the surveyed species in online databases BIOMED, Scopus, SciDirect and GoogleSchoolar, as well as in related literature (Milliken 1997a).

\section{RESULTS}

The 52 interviewees were 18 women and 34 men, with an average age of approximately 52 years. In terms of ethnicity, $73 \%$ of interviewees considered themselves indigenous, including 26 (50\%) Baré, three Tukano, two Baniwa, two 


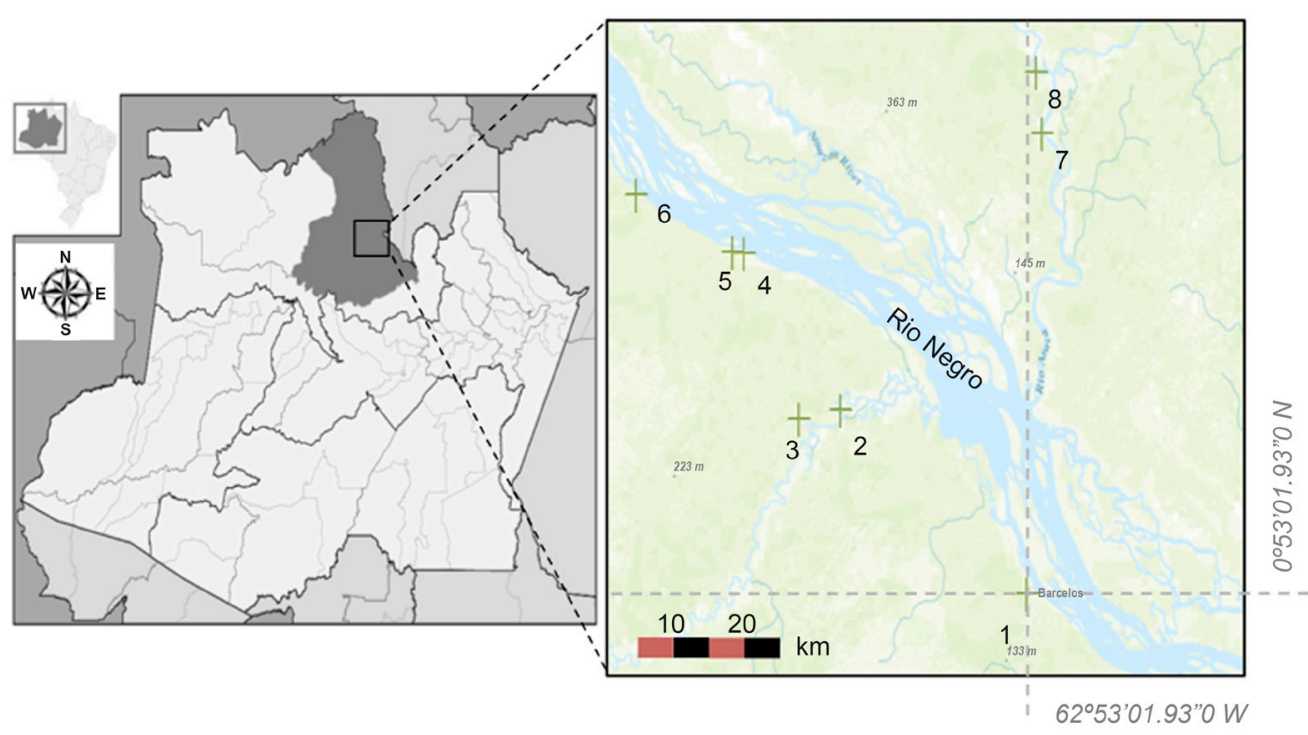

Figure 1. Location of the municipality of Barcelos, Amazonas, Brazil. Numbers indicate the communities surveyed in this study: Barcelos (1), Ponta da Terra (2), Santa Inês (Bulixu) (3), São Luís (4), Cumaru (5), Baturité (6), Bacabal (7), and Romão (8). This figure is in color in the electronic version.

Table 1. Communities visited for the survey of antimalarial plants in the municipality of Barcelos, Amazonas, Brazil

\begin{tabular}{|c|c|c|c|c|}
\hline \multirow{2}{*}{ Community } & \multicolumn{2}{|c|}{ Location } & \multirow{2}{*}{ Population } & \multirow{2}{*}{ Specialists interviewed } \\
\hline & Coordinates & River & & \\
\hline Barcelos (urban zone) & 058'30'S, 62055'26”'W & Negro & $27,110^{1}$ & 4 \\
\hline Ponta da Terra & 0॰45'59"S; 6311'55"W & Quiuini & $78^{2}$ & 9 \\
\hline Santa Inês (Bulixu) & $0^{\circ} 50^{\prime} 54^{\prime \prime S} ; 63^{\circ} 18^{\prime} 24^{\prime \prime W}$ & Quiuini & $56^{2}$ & 8 \\
\hline Cumarú & $0^{\circ} 36^{\prime} 10^{\prime \prime} \mathrm{S} ; 63^{\circ} 23^{\prime} 6^{\prime \prime} \mathrm{W}$ & Negro & $128^{2}$ & 7 \\
\hline São Luíz & 0³7’49”S; 63¹7’54”W & Negro & $63^{2}$ & 5 \\
\hline Baturité & 0³1'41'”S, 6332'46”'W & Negro & 10 & 6 \\
\hline Romão & $0^{\circ} 20^{\prime} 44^{\prime \prime S}$; $62^{\circ} 59^{\prime} 11^{\prime \prime} \mathrm{W}$ & Aracá & $39^{2}$ & 7 \\
\hline Bacabal & 0²2'29"S; 6255’40”W & Demeni & $79^{2}$ & 6 \\
\hline
\end{tabular}

Source: '1BGE, 2013; ²Barra and Dias, 2013

Yanomami, two Kaxinawá, one Tariano, one Urubu Tapira, and one Arapaço.

Concerning the incidence of malaria, only three people reported that they never contracted the disease. All interviewees claimed that their last cases of malaria were contracted in other communities, particularly those in the urban zone of Barcelos. Regarding disease transmission, 53\% of interviewees believed that transmission is via mosquitoes, known locally as carapanã, $6 \%$ believed that transmission is through the water, $25 \%$ believed that both water and mosquitoes facilitate transmission, and $16 \%$ claimed not to know how transmission occurs. Almost half of the interviewees (44\%) reported they did not know any preventive method against contracting malaria. Most interviewees (67\%) said they use pharmaceutical drugs in addition to medicinal plants to treat malaria, $18 \%$ said they only use pharmaceutical drugs, and $15 \%$ said they only use plants and natural remedies.

Our survey resulted in the identification of 55 species belonging to 29 botanical families that are used for the treatment of malaria (Table 2). Some plants referred locally by the same name have been classified by botanical specialists as distinct species. These included açaí (Euterpe spp.), which was later identified as three different species of the same genus; carapanaúba (Aspidosperma spp.), which turned out to be three different species; and sucuúba (Himatanthus spp.), which was represented by two distinct species. Herein these species were considered in accordance with their common local denomination, since species under the same local name belonged to the same genus and were morphologically similar.

The families identified most frequently for the treatment of malaria were Apocynaceae (41 times), Simaroubaceae (15 times), 
Table 2. Antimalarial plants used in the municipality of Barcelos, Amazonas, Brazil. Species marked with an asterisc $\left(^{*}\right)$ were tested in biological essays. Voucher number refers to the identification of the EAFM herbarium. $\mathrm{N}$ citations=number of interviewed specialists that cited this plant followed by the percentage of total interviewees in parentheses; Other sources =other published works that cited the same use; NA=not available. N citations and rank for Aspidosperma, Euterpe and Phanera species are presented as one value because they were considered as only one species by the interviewees.

\begin{tabular}{|c|c|c|c|c|c|c|c|c|}
\hline Family & Species & $\begin{array}{l}\text { Herbarium } \\
\text { voucher } \mathrm{nr}\end{array}$ & Local name & $\begin{array}{c}\text { Part used / } \\
\text { preparation } \\
\text { method }\end{array}$ & $\begin{array}{c}\mathrm{N} \\
\text { citations }\end{array}$ & $\begin{array}{l}\text { Citation } \\
\text { rank }\end{array}$ & Origin & $\begin{array}{l}\text { Other } \\
\text { sources }\end{array}$ \\
\hline Amaranthaceae & Alternanthera sessilis (L.) R.Br. & 10546 & cibalena & leaf as infusion & $1(2 \%)$ & 9 & Amazonia & NA \\
\hline Apocynaceae & $\begin{array}{l}\text { Aspidosperma nitidum Benth. Ex Müll. } \\
\text { Arg. }\end{array}$ & 10561 & carapanaúba & bark decoction & - & - & Amazonia & 1,2 \\
\hline Apocynaceae & Aspidosperma schultesii Woodson* & 10607 & carapanaúba & bark decoction & - & - & Amazonia & 3 \\
\hline Apocynaceae & Aspidosperma sp. & 10551 & carapanaúba & bark decoction & $\begin{array}{c}36 \\
(69 \%)\end{array}$ & 1 & Amazonia & $1,4,5$ \\
\hline Apocynaceae & Geissospermum sp. & NA & quina & bark decoction & $1(2 \%)$ & 9 & Amazonia & $\begin{array}{c}1,2,4,6 \\
7,8\end{array}$ \\
\hline Apocynaceae & Himatanthus stenophyllus Plumel & 10654 & sucuuba & $\begin{array}{l}\text { latex and bark } \\
\text { decoction }\end{array}$ & $3(6 \%)$ & 7 & Amazonia & NA \\
\hline Apocynaceae & $\begin{array}{c}\text { Himatanthus sucuuba (Spruce ex } \\
\text { Müll.Arg.) Woodson }\end{array}$ & 10504 & sucuuba & bark decoction & $3(6 \%)$ & 7 & Amazonia & 1,9 \\
\hline Arecaceae & Astrocaryum aculeatum G.Mey & NA & tucumã & $\begin{array}{l}\text { toasted palm } \\
\text { heart as infusion }\end{array}$ & $1(2 \%)$ & 9 & Amazonia & 3,5 \\
\hline Arecaceae & Euterpe catinga Wallace & NA & açai-caatinga & root decoction & $\begin{array}{c}11 \\
(21 \%)\end{array}$ & 2 & Amazonia & 3 \\
\hline Arecaceae & Euterpe oleracea Mart. & NA & açai-do-pará & root decoction & - & - & Amazonia & $1,4,5$ \\
\hline Arecaceae & Euterpe precatoria Mart.* & NA & açaí; iwapixuna & root decoction & - & - & Amazonia & $1,3,5,9$ \\
\hline Arecacea & Socratea exorrhiza (Mart.) H.Wendl & NA & paxiubinha & $\begin{array}{l}\text { leaf stalk infu- } \\
\text { sion }\end{array}$ & $1(2 \%)$ & 9 & Amazonia & 5 \\
\hline Asteraceae & Artemisia vulgaris L.* & 10556 & cibalena & shoot infusion & $1(2 \%)$ & 9 & $\begin{array}{c}\text { Europe, } \\
\text { Asia, Africa }\end{array}$ & 1,9 \\
\hline Asteraceae & Bidens cynapiifolia Kunth & 10563 & $\begin{array}{l}\text { picão, picão } \\
\text { preto }\end{array}$ & $\begin{array}{l}\text { whole plant } \\
\text { infusion }\end{array}$ & $1(2 \%)$ & 9 & Amazonia & 1,5 \\
\hline Asteraceae & $\begin{array}{l}\text { Gymnanthemum amygdalinum } \\
\text { (Delile) Sch.Bip.* }\end{array}$ & 10611 & $\begin{array}{l}\text { boldo-de- } \\
\text { árvore }\end{array}$ & leaf infusion & $1(2 \%)$ & 9 & $\begin{array}{l}\text { Tropical } \\
\text { Africa }\end{array}$ & $1,5,6,10$ \\
\hline Asteraceae & Mikania psilostachya DC. & 10562 & lingua-de-onça & leaf infusion & $2(4 \%)$ & 8 & Amazonia & NA \\
\hline Asteraceae & Unxia camphorata L.f. & 10623 & são-joão-caá & leaf infusion & $1(2 \%)$ & 9 & Amazonia & 3 \\
\hline Bignoniaceae & $\begin{array}{l}\text { Handroanthus barbatus } \\
\text { (E.Mey.) Mattos }\end{array}$ & 10657 & caapitari & leaf infusion & $2(4 \%)$ & 8 & Amazon & NA \\
\hline Caricaceae & Carica papaya L.* & NA & mamão & leaf inhalation & $1(2 \%)$ & 9 & $\begin{array}{l}\text { Central } \\
\text { America }\end{array}$ & $1,3,4$ \\
\hline Convovulaceae & Bonamia ferruginea (Choisy) Hallier f. & 10582 & cipó-tuira & leaf infusion & $2(6 \%)$ & 7 & Amazonia & $\begin{array}{c}5,9,11 \\
12\end{array}$ \\
\hline Dilleniaceae & Doliocarpus magnificus Sleumer & 10603 & Cipó d’água & leaf infusion & $1(2 \%)$ & 9 & Amazonia & NA \\
\hline Euphorbiaceae & Croton cajucara Benth. * & 10537 & sacaca & leaf infusion & $8(15 \%)$ & 3 & Amazonia & 1,5 \\
\hline Euphorbiaceae & Jatropha curcas L.* & 10543 & pinhão-branco & $\begin{array}{l}\text { seed infusion as } \\
\text { emetic }\end{array}$ & $1(2 \%)$ & 9 & Amazonia & 1 \\
\hline Euphorbiaceae & Manihot esculenta Crantz & NA & mandioca & root flour & $1(2 \%)$ & 9 & Amazonia & 5 \\
\hline Fabaceae & Copaifera sp. & NA & copaíba & $\begin{array}{l}\text { resin in alcohol } \\
\text { extract }\end{array}$ & $1(2 \%)$ & 9 & Amazon & 1,4 \\
\hline Fabaceae & Phanera sp. & 10589 & $\begin{array}{l}\text { escada-de- } \\
\text { jabuti }\end{array}$ & stalk decoction & $3(6 \%)$ & 7 & Amazonia & 1,9 \\
\hline Fabaceae & Phanera splendens (Kunth) Vaz* & 10554 & $\begin{array}{l}\text { escada-de- } \\
\text { jabuti }\end{array}$ & stalk decoction & - & - & Amazonia & 1,3 \\
\hline
\end{tabular}


Table 2. Continuation.

\begin{tabular}{|c|c|c|c|c|c|c|c|c|}
\hline Family & Species & $\begin{array}{l}\text { Herbarium } \\
\text { voucher nr }\end{array}$ & Local name & $\begin{array}{l}\text { Part used / } \\
\text { preparation } \\
\text { method }\end{array}$ & $\begin{array}{c}\mathrm{N} \\
\text { citations }\end{array}$ & $\begin{array}{l}\text { Citation } \\
\text { rank }\end{array}$ & Origin & $\begin{array}{l}\text { Other } \\
\text { sources }\end{array}$ \\
\hline Fabaceae & Phaseolus vulgaris L. & NA & feijão & seed soup & $2(4 \%)$ & 8 & $\begin{array}{l}\text { Central } \\
\text { America }\end{array}$ & NA \\
\hline Fabaceae & Senna occidentalis (L.) Link* & 10662 & feijãozinha & $\begin{array}{l}\text { seeds toasted as } \\
\text { coffee }\end{array}$ & $1(2 \%)$ & 9 & Amazonia & $\begin{array}{l}1,6,9 \\
11,13\end{array}$ \\
\hline Gentinaceae & Potalia resinifera Mart. & 10590 & surucucu-mirá & bark decoction & $7(13 \%)$ & 4 & Amazonia & 14 \\
\hline Icacinaceae & Poraqueiba sericea Tul. & 10599 & umari & seeds cooked & $1(2 \%)$ & 9 & Amazonia & NA \\
\hline Lamiaceae & $\begin{array}{l}\text { Plectranthus amboinicus } \\
\text { (Lour.) Spreng. }\end{array}$ & 10640 & hortelã & leaf infusion & $1(2 \%)$ & 9 & Africa & NA \\
\hline Lamiaceae & Plectranthus ornatus Codd & 10610 & boldo & leaf infusion & $3(6 \%)$ & 7 & $\begin{array}{l}\text { Europe, } \\
\text { Asia }\end{array}$ & NA \\
\hline Lauracea & Persea americana Mill. * & NA & abacate & $\begin{array}{l}\text { toasted leaf } \\
\text { infusion }\end{array}$ & $1(2 \%)$ & 9 & $\begin{array}{l}\text { Central } \\
\text { America }\end{array}$ & $1,3,5,9$ \\
\hline Lecythidaceae & Bertholletia excelsa Bonpl.* & 10553 & castanheira & bark decoction & $7(13 \%)$ & 4 & Amazonia & $1,5,6$ \\
\hline Lecythidaceae & Eschweilera sp. & 10596 & mata-mata & bark decoction & $1(2 \%)$ & 9 & Amazonia & NA \\
\hline Meliaceae & Guarea pubescens (Rich.) A.Juss. & 10655 & jatoá & $\begin{array}{l}\text { bark and liber } \\
\text { decoction }\end{array}$ & $3(6 \%)$ & 7 & Amazonia & 5 \\
\hline Menispermaceae & Abuta grandifolia (Mart.) Sandwith & 10598 & pitombinha & leaf infusion & $2(4 \%)$ & 8 & Amazonia & 1,4 \\
\hline Menispermaceae & Abuta imene (Mart.) Eichler & 10615 & cipó-abuta & root decoction & $4(8 \%)$ & 6 & Amazon & NA \\
\hline Myristicaceae & Iryanthera hostmannii (Benth.) Warb. & 10595 & ucuí & sap & $2(4 \%)$ & 8 & Amazonia & NA \\
\hline Myrtaceae & Eucalyptus sp.* & NA & eucalipto & leaf infusion & $1(2 \%)$ & 9 & Australia & 1,11 \\
\hline Poaceae & Paspalum gardnerianum Nees & 10547 & расuã & $\begin{array}{l}\text { whole plant } \\
\text { infusion }\end{array}$ & $1(2 \%)$ & 9 & Amazonia & NA \\
\hline Rhamnaceae & Ampelozizyphus amazonicus Ducke* & 10567 & saracura mirá & $\begin{array}{l}\text { root and liber } \\
\text { decoction }\end{array}$ & $7(13 \%)$ & 4 & Amazonia & $\begin{array}{c}1,3,5 \\
6,9\end{array}$ \\
\hline Rubiaceae & Coffea sp. & NA & café & $\begin{array}{l}\text { toasted leaf } \\
\text { infusion }\end{array}$ & $1(2 \%)$ & 9 & Africa & $1,7,9$ \\
\hline Rutaceae & Citrus limon (L.) Osbeck & 10581 & limão & $\begin{array}{l}\text { dried fruit peel } \\
\text { infusion }\end{array}$ & $1(2 \%)$ & 9 & Asia & $1,3,5$ \\
\hline Rutaceae & Citrus sp. & NA & laranja & $\begin{array}{l}\text { dried fruit peel } \\
\text { infusion }\end{array}$ & $1(2 \%)$ & 9 & Asia & $1,3,5$ \\
\hline Selaginellaceae & Selaginella sp. & 10538 & samambaia & leaf decoction & $1(2 \%)$ & 9 & Amazonia & NA \\
\hline Simaroubaceae & Quassia amara L.* & 10569 & quina & leaf infusion & $8(15 \%)$ & 3 & Amazonia & $1,5,9$ \\
\hline Simaroubaceae & Simaba cedron Planch. * & 10591 & pau-pra-tudo & bark decoction & $7(13 \%)$ & 4 & Amazonia & $1,5,9$ \\
\hline Solanaceae & Capsicum frutescens $\mathrm{L}$. & 10641 & malagueta & $\begin{array}{l}\text { whole plant } \\
\text { infusion }\end{array}$ & $4(8 \%)$ & 6 & America & 1 \\
\hline Solanaceae & Physalis angulata L.* & 10549 & сатари & root decoction & $5(10 \%)$ & 5 & America & $1,3,9$ \\
\hline Solanaceae & Solanum stramoniifolium Jacq. & 10574 & jurubeba & root decoction & $2(4 \%)$ & 8 & Amazonia & NA \\
\hline Urticaceae & Cecropia ficifolia Warb. ex Snethl. & 10604 & $\begin{array}{c}\text { embaúba- } \\
\text { branca }\end{array}$ & leaf inhalation & $1(2 \%)$ & 9 & Amazonia & NA \\
\hline Verbenaceae & $\begin{array}{c}\text { Stachytarpheta cayennensis } \\
\text { (Rich.) Vahl* }\end{array}$ & 10571 & gervão & leaf infusion & $1(2 \%)$ & 9 & Amazonia & $1,5,9$ \\
\hline Zingiberaceae & $\begin{array}{l}\text { Alpinia zerumbet (Pers.) } \\
\text { B.L.Burtt \& R.M.Sm. }\end{array}$ & 10639 & vindicá & leaf infusion & $1(2 \%)$ & 9 & $\begin{array}{l}\text { China, } \\
\text { Japan }\end{array}$ & NA \\
\hline
\end{tabular}

1- Milliken (1997a), 2- Steele et al. (2002), 3- Kffuri et al. (2016), 4- Ferreira et al. (2015), 5- Frausin et al. (2015), 6- Brandão et al. (1992), 7- Botsaris (2007), 8- Deharo and Ginsburg (2011), 9- Hidalgo (2003), 10- Madureira (2008), 11-Caraballo et al (2004), 12- Idowu et al. (2010), 13- Nguta et al. (2010), 14- Ruiz et al. (2011) 
Asteraceae (14 times), Arecaceae (13 times), and Rhamnaceae (12 times). Regarding the origin of the identified species, $82 \%$ are native to the Amazon region and 18\% are exotic.

Of the 52 plants identified for the treatment of malaria, 16 have not been previously described in other published works (Alternanthera sessilis, Himatanthus stenophyllus, Mikania pilostachya, Handroanthus barbatus, Phaseolus vulgaris, Doliocarpus magnificus, Poraqueiba sericea, Eschweilera sp., Plectranthus amboinicus, Plectranthus ornatus, Abuta imene, Iryanthera hostmannii, Paspalum gardnerianum, Solanum stramoniifolium, Cecropia ficifolia and Alpinia zerumbet) (Table 2). Only 25 of the plants identified in the present study have been characterized pharmacologically (Table 2 ).

The interviewees considered that approximately $65 \%$ of the plants reported for malaria treatment are bitter and eleven of the 12 most frequently identified plants for malaria treatment were considered bitter. A wide variety of plant parts were used, as well as several preparation methods (Table 2).

On average, the interviewed women identified eight antimalarial plants while men identified six. Among the plants indicated by women, $54 \%$ grow in intensively managed (domesticated) environments, such as backyards and small fields, while $61 \%$ of the plants indicated by men grow in wild environments, such as terra firme and floodplain forests.

\section{DISCUSSION}

More than 30\% of interviewees believed that water was the sole or partial transmission agent of malaria. This association of malaria transmission with water can be explained by the higher incidence of the disease during the rainy season (November to March) (SVS 2015), when the breeding and consequent abundance of the Anopheles vectors increases significantly. The still widespread misconception about the transmission mode of the disease, as well as the widespread ignorance about preventative methods reflects the low effectiveness of awareness campaigns by local health officials, which makes the control of the disease more difficult. The use of medicinal plants may also be related to the ineffective coverage of health provision services. The majority of interviewees stated that they relay on pharmaceuticals for malaria treatment, and medicinal plants were used mainly for the treatment of malaria symptoms such as headache, fever, body aches, liver problems, and anemia. However, the use of plants for the treatment of the malaria infection in itself, occurred specially in communities with low access to conventional public health providers.

The most frequently identified species for the treatment of malaria in the present study were carapanaúba (Aspidosperma spp.), saracura-mirá (Ampelozizyphus amazonicus), açaí (Euterpe spp.), picão (Bidens pibinatifolia), sacaca (Croton crajucara), and quina (Quassia amara) (Table 2), which is in agreement with other similar studies carried out in the Amazon region (Brandão et al. 1992; Milliken 1997b; Hidalgo 2000; Frausin et al. 2014; Ferreira et al 2015; Kffuri et al. 2016). All of these plants have proven effective in the control of malaria Plasmodium (Milliken 1997a; Mariath et al. 2009; Nunomura and Pohlit 2010), except for B. bipinatifolia that has not yet been tested. Thus our results support the notion that the species more commonly used, and therefore empirically approved by more people, are also those proven to be efficient for disease treatment when tested scientifically.

The use of these medicinal plants was also influenced by their accessibility. For instance, saracura-mirá (Ampelozizyphus amazonicus), the second most frequently cited plant in this study, occurs only in specific places according to the interviewees, sometimes far from their home, and is only used when they have access to it. Some plants were rather used as substitutes for prefered plants, like paxiubinha (Socratea exorrhiza), that was used when the interviewees could not find carapanaúba (Aspidosperma ssp.).

Apocynaceae was the botanical family with the greatest number of species (six) used to treat malaria, followed by Arecaceae (five), Asteraceae (five), and Fabaceae (four), as has been observed in other antimalarial plant surveys in the Amazon region (Brandáo et al. 1992; Hidalgo 2000; Frausin et al. 2014; Ferreira et al. 2015; Kffuri et al. 2016). These families are among those with the highest species diversity in the Amazon region (Flora do Brasil 2020 em construção 2017). However, when considering the ratio of total species number by family to those of antimalarial value in traditional pharmacopeia, Simaroubaceae would be the most important plant family for the treatment of malaria, since $20 \%$ of all Simaroubaceae species that occur in the Amazon were reported to be used for the treatment of this disease, while only $3.4 \%$ of Apocynaceae species occurring in the region were reported as antimalarial (Milliken 1997a; Mariath et al. 2009; Flora do Brasil $2020 \mathrm{em}$ construção 2017). The relatively high use of exotic species in popular pharmacopoeia is a result of population influx of other regions, which is common in northern South America (Bennet and Prance 2000) and in Barcelos (Barra and Dias 2013).

The predominance of bitter taste in plants used for malaria treatment was observed in other studies (Brandáo et al. 1992; Hidalgo 2000). This may result from the relationship with the bitter taste of the real quina (Cinchona spp.) and its active component (quinine) that is used in the allopathic medicine, or with other antimalarial plants used by local populations that are considered bitter and have been proven effective in parasite control, such as sacaca (Croton cajucara), carapanaúba (Aspidosperma spp.), or quina (Quassia amara) (Milliken 1997a; Mariath et al. 2009).

Which plant part is used for treatment reflects the variety of growing habits of the species used. Commonly used materials 
from trees were bark and timber, while that from herbs were leaves. The plant part used largely determines the preparation method. Seeds and bark are usually decocted, while leaves are rather used in infusion. These aspects are important for the evaluation of the sustainable exploration of these plants, but should be considered on an individual case basis.

The generally higher number of antimalarial plants identified by women is probably due to the fact that, traditionally, women are responsible for the family's health. In the northeast of Brazil women have been found to have more knowledge about the use of medicinal plants (Voeks 2007). The differential association of men and women with domesticated and wild medicinal plant species likely stems from the role partition between the genders. Men fish and hunt, having more contact with the wild areas around the communities, while women spend most of their working hours in backyards and farm fields (Ribeiro 1995). The interviewees who identified a higher number of plants for malaria treatment had some form of written record of the use of medicinal plants, which suggests that the knowledge of medicinal plants should also be related to the memory of each person.

\section{CONCLUSIONS}

The knowledge of the use of antimalarial plants is well developed in communities of the Barcelos municipality at the middle Negro River, where the incidence of malaria is still high. We report 55 plants used to treat malaria infection, among them 16 species that had not been previously mentioned in other publications as antimalarial. Local women specialists cited more antimalarial plants than men, and cited more plants related to domestic environments, while men cited more plant species found in surrounding forests. Most antimalarial plants used by local people were bitter tasting. The exclusive use of plants for malaria treatment tends to be higher where conventional health providers are absent. Other factors could be involved with the use of antimalarial plants, but must be more studied, such as the accessibility of these plants and thei efficiency and safety. Of the 55 reported species, only 25 have been characterized through biological essays, which highlights the importance of ethnobotanical research for the identification of potential novel antimalarial drugs.

\section{ACKNOWLEDGEMENTS}

The authors are grateful to the population of Barcelos, and, in particular, to the Association of Indigenous Communities of Barcelos (ASSIBA), to the Foundation for Health Vigilance of Barcelos (FVS), to the Barcelos Health Secretary, and to the Special Secretary for Indigenous Health from the National Health Ministry (DSEI/Barcelos). This research was funded by Fundação CAPES, Fundação de Amparo à Pesquisa de São
Paulo (FAPESP), and Conselho Nacional de Desenvolvimento Científico e Tecnológico (CNPq).

\section{REFERENCES}

Alecrim, M.G.C.; Alecrim, W.; Macedo, V. 1999. Plasmodium vivax resistence to chloroquine (R2) and mefloquine (R3) in Brazilian Amazona Region. Revista da Sociedade Brasileira de Medicina Tropical, 32: 67-68.

Alexiades, M. 1996. Selected Guidelines for ethnobotanical research: a field manual. The New York Botanical Garden, New York, 306p.

Barra, C.S.; Dias C. 2013. Barcelos indígena e ribeirinha: um perfil socioeconômico. ASIBA/FOIRN/ISA, São Paulo, 82p.

Bennet, B.C.; Prance, G.T. 2000 Introduced plants in the indigenous pharmacopoeira of northerns South America. Economic Botany, 54: 90-102.

Botsaris, A.S. 2007. Plants used traditionally to treat malaria in Brazil: the archives of Flora Medicinal. Journal of Ethnobiology and Ethnomedicine, 65: 3-18.

Brandão, M.G.L.; Grandi, T.S.M.; Rocha, E.M.M.; Sawyer, D.R.; Krettli, A.U. 1992. Survey of medicinal plants used as antimalarials in the Amazon. Journal of Ethnopharmacology, 36: 175-82.

Bremem, J. 2011. The ears of the hippopotamus: manifestations, determinants, and estimates of the malária burden. American Journal of Tropical Medicine and Hyggene. 64: 1-11.

Caraballo, A.; Caraballo, B.; Rodrigues-Acosta, A. 2004. Preliminary assessment of medicinal plants used as antimalarials in the southeastern Venezuelan Amazon. Revista da Sociedade Brasileira de Medicina Tropical, 37: 186-188.

Carvalho, L.H.; Krettli, A.U. 1991. Antimalarial chemotherapy with natural products and chemically defined molecules. Memórias do Instituto Oswaldo Cruz, 86: 181-184.

Coimbra Jr, C.E.A. 1998. Human factors in the epidemiology of malaria in the Brazilian Amazon. Human Organization, 47: 254-260.

Deharo, E.; Ginsburg H. 2011. Analyses of additivity and synergism in the anti-plasmodial effect of purified compounds from plant extracts. Malaria Journal 10(S1): S5. (http://www.malariajournal. com/content/10/S1/S5)

Ferreira, A.; Ming, L.C.; Haverroth, M.; Daly, D.; Caballero, J.; Ballesté, A. 2015. Plants Used to Treat Malaria in the Regions of Rio BrancoAcre State and Southern Amazonas State - Brazil. International Journal of Phytocosmetics and Natural Ingredients, 2015: 2-9.

Flora do Brasil 2020 em construção. 2017. Jardim Botânico do Rio de Janeiro (Rio de Janeiro Botanical Garden). (http://floradobrasil. jbrj.gov.br/). Accessed on 19 Feb 2017.

Frausin, G.; Hidalgo, A.F.; Lima, R.B.S.; Kinupp, V.F.; Ming, L.C.; Pohlit, A.M.; Milliken, W. 2015. An ethnobotanical study of anti-malarial plants among indigenous people on the upper Negro River in the Brazilian Amazon. Journal of Ethnopharmacology, 215: 238-252.

Frits, F.J.; Franssen, F.F.J.; Smeijters, L.J.J.W.; Berger, I.; Aldana, B.E.M. 1997. In vivo and In vitro antiplasmodial activities of some plants traditionally used in Guatemala against malaria. Antimicrobial Agents and Chemotherapy, 41: 1500-1503. 
Ginsburg, H.; Deharo, E. 2011. A call for using natural compounds in the development of new antimalarial treatments - an introduction. Malaria Journal 10(S1): S1. (http://www. malariajournal.com/content/10/S1/S1)

Graz, B. 2004. Observational methods for assissing Traditional antimalarial. In; Willcox, M., Bodeker, G., Rasoanauvi, P. (Ed.). Traditional Medicinal Plants and Malaria. CRC Press, New York, p.240-276.

Graz, B.; Kitua, A; Maledo, H.M. 2011. To what extent can traditional medicine contribute a complementary or alternative solution to malaria control programmes. Malaria Journal 10(S1): S6. (http://www.malariajournal.com/content/10/S1/S6)

Hidalgo, A.F. 2003. Plantas de uso popular para o tratamento da malária e males associados da área de influência do rio Solimóes e região de Manaus - AM. Doctoral Dissertation, Department of Horticulture, Faculdade de Ciências Agronômicas, Universidade Estadual Paulista, Botucatu. 192p.

IBGE. 2016. Informaçôes sobre o municipio de Barcelos, Amazonas. (http://www.cidades.ibge.gov.br/xtras/perfil. php?lang=\&codmun=130040). Accessed on 01 Feb 2016.

Idowu, O.A.; Soniran, O.T.; Ajana, O.; Aworinde, D.O. 2010. Ethnobotanical survey of antimalaria plants used in Ogun State, Southwest Nigeria. African Journal of Pharmacy and Pharmacology, 4: 55-60.

Jensen, J.F.; Kvist, L.P.; Christensen, S.B. 2002. An antiplasmodial lignan from Euterpe precatoria. Journal of Natural Products, 65: 1915-1917.

Kffuri, C.W.; Lopes, M.A.; Ming, L.C.; Odonne, G.; Kinupp, V.F. 2016. Antimalarial plants used by indigenous people of the Upper Rio Negro in Amazonas, Brazil. Journal of Ethnopharmacology, 178: 188-198.

Krettli, A.U. 2008. Grandes Endemias no Brasil. Gazeta Médica da Bahia, 78: 74-78.

Krettli, A.U.; Aandrade-Neto, V.F.; Brandão, M.G.L.; Ferrari, F. 2001. Search for new antimalarial drugs from plants used to treat fever and malaria or plants randomly selected: a review. Memórias do Instituto. Oswaldo Cruz, 96: 1033-1042.

Lima, R.B.; Rocha e Silva, L.F.; Melo, M.R.; Costa, J.S.; Picanço, N.S.; Lima, E.S.; et al. 2015. In vitro and in vivo anti-malarial activity of plants from the Brazilian Amazon. Malaria Journal, 14: 508. (DOI: https://doi.org/10.1186/s12936-015-0999-2)

Mariath, I.R.; Flacão, H.S.; Barbosa-Filho, J.M.; Sousa, L.C.F.; Tomaz, A.C.; Diniz, M.F. et al. 2009. Plants of the American continent with antimalarial activity. Brazilian Journal of Pharmacology, 61: 1401-1433.

Mello, D.A. 1985. Malária entre populações indígenas do Brasil. Cadernos de Saúde Pública, 1: 25-34

Milliken, W. 1997a. Plants for malaria, plants for fever: medicinal species in Latin America - a bibliographic survey. The Royal Botanic Gardens, Kew Gardens, 116p.

Milliken, W. 1997b. Traditional anti-malarial medicine in Roraima, Brazil. Economic Botany, 51: 212-237.

Muñoz, V.; Sauvain, M.; Bourdy, G.; Arrázola, S.; Callapa, J.; Ruiz, G.; Choque, J.; Deharo, E. 2000. A search for natural bioactive compounds in Bolivia through a multidisciplinary approach:
Part III. Evaluation of the antimalarial activity of plants used by Alteńos Indians. Journal of Ethnopharmacology, 71: 123-131.

Nguta, J.M.; Mbaria, J.M.; Gakuya, D.W.; Gathumbi, P.K.; Kiama, S.G. 2010. Traditional antimalaria phytotherapy remedies used by the South Coast community, Kenya. Journal of Ethnopharmacology, 131: 256-267.

Nunomura, S.M.; Pohlit, A.M. 2010. Alcalóides indólicos de casca de Aspidosperma vargasii e A. desmanthum. Quimica Nova, 33: 284-287.

Oliveira, F.Q.; Junqueira, R.G.; Sthemann, J.R.; Brandão, M.G.L. 2003. Potencial das plantas medicinais como fonte de novos antimaláricos: espécies indicadas na bibliográfica etnomédica brasileira. Revista Brasileira de Plantas Medicinais, 5: 23-31.

Ribeiro, B. 1995. Os índios das águas pretas. Companhia das Letras, Sáo Paulo, 270p.

Sá, M.S; Menzes, M.N.; Krettli, A.U; Tomassini, R.T.C.B; Santos, R.R; Azevedo, J.R.W.F; Soares, M.B.P. 2011. Antinalarial activity of Physalins B, D, F and G. Natural Products, 74: 2269-2272.

Silva, A.L.; Tamashiro, J.; Begossi, A. 2007. An ethnobotany of the riverine population from the Rio Negro, Amazonia (Brazil). Journal of Ethnobiology, 27: 46-72.

Singer, B.H.; Caldas, M.C. 2001. Agricultural colonization and malaria on the Amazon frontier. Annals of the New York Academy of Sciences, 954: 184-222.

Spencer, C.F.; Koniuszy, F.R.; Rogers, E.F.; Shavel Junior, J.; Easton, N.R.; Kaczka, E.A.; et al. 1947. Survey of plants for antimalarial activity. Lloydia, 10: 145-174.

Suárez-Muttis, M.C.; Coura, J.R. 2007. Mudanças no padrão epidemiológico da malária em área rural do médio rio Negro, Amazônia brasileira: análise retrospectiva. Cadernos da Saúde Pública, 23: 785-804.

Suffredini, I.B.; Daly, D.C. 2001. O rio Negro como cenário na busca de novos medicamentos. In: Oliveira, A.A., Daly, D.C. (Ed.). Florestas do rio Negro. Companhia das Letras, São Paulo, p.340-365.

SVS. 2015. Boletim epidemiológico. Ministério da Saúde 46(25). (http://portalsaude.saude.gov.br/images/pdf/2015/ agosto/18/2015-009---Mal--ria-para-publica----o.pdf). Accessed on 19 Nov 2015.

Voeks, R.A. 2007. Are women reservoirs of traditional plant knowledge? Gender, ethnobotany and globalization in northeast Brazil. Singapore Journal of Tropical Geography, 28: 7-20

WHO. 2010. Global report on antimalarial drug efficacy and drug resistance. 2000-2010. World Health Organization, Geneve, 843p.

WHO. 2015. World Malaria Report 2015. (http://www.who.int/ malaria/publications/world-malaria-report-2015/report/en/). Accessed on 8 Feb 2016

Willcox, M.; Benoit-Vical, F.; Fowler, D.; Bourdy, G.; Burford, G.; Giani, S., et al. 2010. Do ethonobotanical and laboratory data predict clinical safety and efficacy of anti-malaria plants? Malaria Journal, London 10(S1): S7. (http://www.malariajournal.com/ content/10/S1/S7)

Received: $18 / 04 / 2017$

Accepted: 08/06/2017 


\section{SUPPLEMENTARY MATERIAL}

(only available in the electronic version)

TOMCHINSKY et al. Ethnobotanical study of antimalarial plants in the middle region of the Negro River, Amazonas, Brazil.

Annex S1. Questionnaire used in the survey 
